\title{
Using Video Subscribe to Improve Students' Speaking Ability
}

\author{
Refika Andriani ${ }^{1}$, Adhella Putri ${ }^{2}$, Destina Kasriyati ${ }^{3}$ \\ ${ }^{1}$ Universitas Lancang Kuning, Pekanbaru, Riau, Indonesia \\ e-mail: andrianirefika86@gmail.com \\ ${ }^{2}$ Universitas Lancang Kuning, Pekanbaru, Riau, Indonesia \\ e-mail: adhella765@gmail.com \\ ${ }^{3}$ Universitas Lancang Kuning, Pekanbaru, Riau, Indonesia \\ e-mail: destina@unilak.ac.id
}

\begin{abstract}
:
Based on the preliminary research, it was found that Junior High School Students of IT AlBirru Pekanbaru's speaking skill regarding to recount text was very poor. So, the researcher decided to conduct a Classroom Action Research by using Video Subscribe to improve their speaking skill. It can be stated that the research aims at improving the students of Junior High School of IT Al-Birru Pekanbaru's speaking skill by using Video Subscribe. The respondents of the research were twenty students of grade VIII.1, Junior High School of IT Al-Birru Pekanbaru. This research was done in a cycle with four meetings and a test. For collecting the data, a test, an observation checklist, field notes, and an interview were distributed. After analyzing the data in cycle I, it was found that the students' speaking ability was improved. It was proved by the students' speaking criteria score; accent was about 60; grammar was about 74; vocabulary was about 79; fluency was about 72; and comprehension was about 78 . So, the average score of students' speaking ability was 72.4. This students' speaking improvement was influenced by a factor namely interest. In the other hands, this video subscribe was very interesting media so it could encourage the students' participation and confidence during the process of learning activity especially in speaking regarding to recount text. No more students were inactive. They tended to be focus and active in doing communication such as addressing questions and giving comments.
\end{abstract}

\section{Keywords: Video subscribe, Speaking, Recount text}

\section{INTRODUCTION}

Speaking is one of the four skills of the language. Because it is a productive skill, speaker must be able in mastering communicative performance and other elements such as pronunciation, grammar, vocabulary, and comprehension well. Those elements must be taught in any language learning to enable the students using the target language for communication. It is an important skill in learning a language, where probably most learners wish to be able to use it fluently for communication. Based on the English syllabus of curriculum 2013, it is stated that the students of grade VIII should be able to familiarize and master about recount. In means that they are not only required to be able to write well but also be able to speak in front of class related to the topic given.

Cameroon (2001: 40) says that speaking is active use of language and 
expresses meaning so that other people can easily understand it. Moreover, it has been recognized as an interactive, social, and contextual communication tool. Speaking requires students to know how to produce not only linguistically connected but also pragmatically appropriate speech. In other words, it is clear that speaking is the use of verbal language important for communicating well. Speaking is the ability of people to express their ideas to others to understand what they want to mean by the speaker and the listener. It is a demanding skill that should have to develop or improved to communicate with other.

According to Nunan (2003), teaching students to communicate in English is not easy especially for non-native speaker such as in Indonesia. The difficulty of learning English may come from the environment. For instance, students almost never hear their family or community speak in English. In addition, they only hear or try to speak English during the time of the lesson. So, they do not have enough time and chance to practice. It is very clear that teaching speaking needs an appropriate strategy or method to help language learners easy to practice how to communicate in target language without any hesitation for mistaken. Besides, Harmer (2001) expresses that the purpose of teaching speaking is to train students to communicate. Besides that, teachers must be able to develop activities that will make students use English in communication. Based on the experts' idea, the researcher concludes that students need to be motivated to practice speaking by using an interest and appropriate strategy. So, the process of teaching and learning how to communicate in English runs well.
Based on the English syllabus of curriculum 2013 applied in Junior High School in Indonesia (Kemendikbud; 2013), teaching and learning speaking concerning to recount text enables the students to analyze and apply the social function of recount text, generic structure, and language features of recount text related to the topic. Students should be able to arrange recount text orally considering social function, generic structure, and language feature correctly. Speaking is not enough by being able to arrange and apply the correct social function, generic structure, and language features of recount text, it is need the ability in delivering the information about experience by using clear pronunciation, intonation, and facial expression. It will minimize misunderstanding between the speaker and the listeners. So, it is easy to understand the meaning of the information. Recount text is very familiar with the students' daily life because it has been students' behavior to tell their friends about personal experiences. They do not need other sources for their content because everyone has their own experience.

Concerning to the preliminary study done at grade VIII.1 at SMP IT Al Birru Pekanbaru during the first semester of 2019, it was found that the students' speaking ability was very poor. Their English speaking score for recount text was about 69. It was indicated by several indicators. First, the student had low selfconfidence when they were asked to speak in front of the class. It made them had difficulty to express the ideas in English. Second, students had lack vocabulary. It was hard for everyone to communicate when they had no words to say. That was 
happened to almost all the students. So, they tended to be silent because did not have any words to say. Third, they do not understand the use of grammar. Every genre of text that should be mastered by the students has generic structure. It is also concerning to the use of grammar of the sentences. It also affected the students' motivation in being active to communicate. Fourth, they have difficulty pronouncing words and their speaking is still influenced by their mother tongue.

Regarding to the phenomenon, the researcher concluded that students actually needed an appropriate strategy or method to improve their motivation in learning especially speaking English. There should be an interesting method use such as using media for attracting the students' interest in following the learning activity. It also would make the teaching and learning process more effective and efficient. So, the students' speaking skill especially about recount could be improved. According to Jonassen et.al. in Chan (2011), teaching uses the media more than vehicles of learning and can be used more productively as a tool to support learners' cognition by freeing them from unproductive tasks and allowing them to focus more fully on the construction of knowledge. Moreover, teaching the media will make learning more effective.

Deakin (2014) states that video subscribe is a popular tool used to engage learners and enhance a learning experience. So, students are easier to understand and memorize the information from the video. Winarko (2012) states that video is one of the modern teaching techniques. Traditional and modern teaching methods are two different terms. In the modern one, teachers should be creative and innovative. It means that the use of video Subscribe can facilitate students in learning activities because they can get different learning experiences when they can be done by the teacher effectively.

Therefore, the researcher used a video subscribe to solve the problem. Because using video as media in teaching speaking activities could be very useful for effective and joyful learning. As Harmer (2001), states that using video in the process of teaching and learning will help the students to hear and also see the language. Using video enable the students to convey the general meaning of the language use though expression, gesture, and another visual clue. Then, video can increase the students' motivation in learning. It because video gives chance for students to see the language in use as heard and it will be perfect if it is completed by communicative task.

In line with that, Muniandy and Veloo (2011: 173) express that video Subscribe is a multimedia material which combine verbal and non-verbal presentation displaying simultaneous images, narration, and on-screen text. McKinnon (2011) adds that video provide an important visual stimulus for language practice and learning because it can portray settings, actions, emotions, and gestures which can. In another word, video subscribe is media that provided audio-visual that used to help in teaching-learning activities that have been subscribed in YouTube. Besides that, Brewster et al (2002: 204) express that some advantages of using video Subscribe in the teaching-learning process involves several aspects such Psychological aspects, linguistics aspects, cognitive aspects, and cultural aspects. It brings a lot of 
advantages in teaching and learning to speak. Using video Subscribe in the teaching process Speaking provides an authentic English model. And it can also serve the language in use. Besides, video Subscribe in speaking enables students to learn appropriate pronunciation, improve vocabulary, and their understanding of different cultures.

In conclusion, video subscribe provides great visual stimuli with the combination of illustrations, sounds, graphics, and texts that can be used in teaching English. Therefore, the use of meaningful video in teaching may be most appropriate for introducing topics and presenting material that is studied by the students. It can foster the students' interest in learning process so they can enjoy every steps of the lesson and participate actively.

\section{METHOD}

This research was classroom action research. As Cresswell (2012) states that action research designs has systematic procedures done collaboratively by teachers (or other individuals in an educational setting) as the researcher and a collaborator to gather information about and subsequently improve, the ways their particular educational setting operates, their teaching, and their student learning. Based on the definition of the expert above, it can be concluded that classroom action research is a type of research design that conducted by the educators aims at improving the students' skill or to solve the students' problems that occur in the learning process by applying an appropriate strategy.

Thus, tis research aimed to improve the students' speaking ability concerning to the recount text by using video subscribes.
It was expected to be able to solve problem related to the English language teaching especially in the process of students learning in the speaking class, improving the students' speaking achievement, and also the quality of teaching English. The participants of this research were the grade VIII.1 students of SMP IT Al Birru Pekanbaru, Academic Year 2019/2020. There were about 20 students.

As proposed by Kemmis and McTaggart (2007), there were four steps of conducting this Classroom Action Research (CAR) involved in a cyclical model. This cycle has plan; action, observation, and reflection. Before implementing the action, the researcher prepared a plan by writing a lesson plan as the guide for teaching and learning process during the research. The researcher, also prepared the video subscribe with some topics concerning to the recount text. In action phase, the researcher implemented the process of teaching and learning focusing on speaking of recount text. This phase was done in four meetings by using video subscribe as the media. During the process of teaching and learning of speaking by using video subscribe, the collaborator would fill the instruments. They were observation checklist and field note. Observation checklist involved the teacher and students' activities in the classroom based on the indicators of using video subscribe in speaking class which was stated in lesson plan. Filed noting required the collaborator to write all the activities of the teacher and students in the learning process. In the last process, the researcher made a reflection based on the result of data analysis from the test, observation checklist, field note, and interview. The researcher made the 
conclusion based on the result of the study. If there was no significant improvement of the students' speaking score in the first cycle, it would be continued to the next cycle. Otherwise, if there was an improvement of the students' speaking score after having being taught by using video subscribe, the researcher would decide to stop the action in that first cycle. Here is the figure of Classroom Action Research procedure proposed by Kemmis and McTaggart.

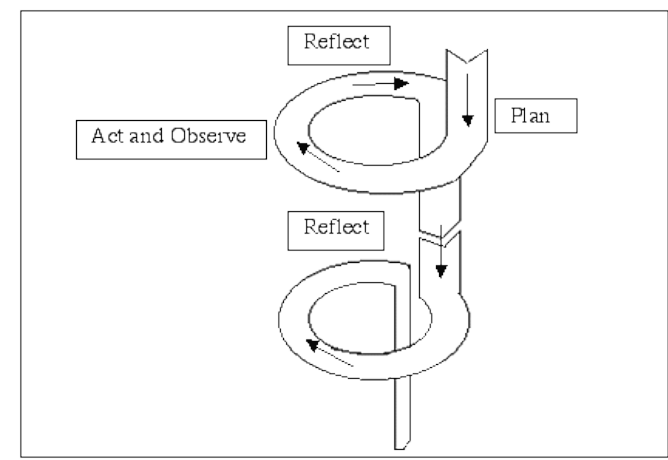

Figure 1. Action Research Cycle

\section{a. Data Collection Technique}

In conducting the research, the researcher used observation checklist and field note during the teaching and learning process by using video subscribe. The collaborator filled the observation checklist and wrote all the teaching and learning activity in the class. After having four meetings of teaching and learning activity using video subscribes, the researcher collected the data about the students' speaking ability by using speaking test. In this case, students asked to speak related to their experiences in the last holiday. Speaking of recount text scoring rubric was used to measure the students' ability. In the last step of data collection, the researcher interviewed the students. It did to get the data regarding to the factors influence the changing of students' speaking ability after having taught by using video subscribes.

\section{b. Data Analyzing Technique}

There were two kinds of data got from the research. First is quantitative data. It was concerning to the result of students' speaking test of recount. Students' speaking test was analyzed by using a speaking scoring rubric adopted from Hughes (2003). There are four indicators of students' speaking ability that would be accessed. They are accent, grammar, vocabulary, fluency, and comprehension. Then, to find out the mean score of students speaking test, researcher used the following formulation suggested by Sugiyono (2007): Where,

$$
M e=\frac{\sum X i}{N}
$$

$$
\begin{array}{ll}
\mathrm{Me} & : \text { Mean } \\
\sum \mathrm{X} & : \text { Epsilon (total score) } \\
X i & : \text { Score } x \text { to } i \text { until } n \\
\mathrm{~N} & : \text { number of participants }
\end{array}
$$

To interpret the level of students' speaking ability, the researcher used the following score classification adopted from Depdiknas (2006).

Table 1. The Students' Speaking Score Classification

\begin{tabular}{ccc}
\hline No & Classification & Score Range \\
\hline 1 & Excellent & $96-100$ \\
\hline 2 & Very Good & $86-95$ \\
\hline 3 & Good & $76-85$ \\
\hline 4 & Fairly Good & $66-75$ \\
\hline 5 & Fair & $56-65$ \\
\hline 6 & Poor & $36-55$ \\
\hline 7 & Very Poor & $0-35$ \\
\hline \multicolumn{2}{c}{ Source: Depdiknas (2006) }
\end{tabular}


In analyzing qualitative data got from observation checklist, field note, and interview, the researcher used some steps such as data managing; reading or memoing; description; classifying; and interpreting. Using this step of analyzing the qualitative data, the researcher was expected to be able to interpret the data and came to the conclusion of the research finding.

\section{FINDINGS AND DISCUSSION}

After conducting all the procedures of the research and having analyzing the data, the researcher decided that this research was completed in a cycle consisted of four meetings and one time speaking test as following.

\begin{tabular}{ccc}
\hline Meeting & Topic & Date \\
\hline 1 & $\begin{array}{c}\text { Explaining } \\
\text { Past tense }\end{array}$ & $\begin{array}{c}20^{\text {th }} \text { of February, } \\
2020\end{array}$ \\
\hline 2 & $\begin{array}{c}\text { My Holiday } \\
\text { In Bali }\end{array}$ & $\begin{array}{c}27^{\text {th }} \text { of February } \\
2020\end{array}$ \\
\hline 3 & At The Beach & $4^{\text {th }}$ of March, 2020 \\
\hline 4 & $\begin{array}{c}\text { My Holiday } \\
\text { In Magelang }\end{array}$ & $5^{\text {th }}$ of March, 2020 \\
\hline 5 & Test & $11^{\text {th }}$ of March, \\
& & 2020
\end{tabular}

Table 2. Research Timetable

The students' speaking ability concerning to recount text was improve after being taught by using video subscribe. It can be seen from the following diagram.

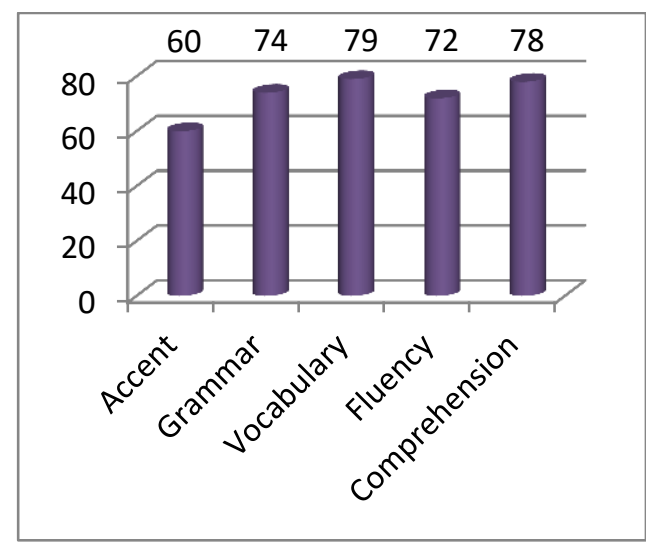

Diagram 1. Students' Speaking Skill Score

The diagram above describes about the students' speaking average score after learning by using video subscribes. It can be seen that the students' accent when speaking English relates to the recount was 60. The students' ability in using correct grammar during speaking was 74 . Then, their ability in choosing words or vocabulary was 79 . Their fluency in communicating the message was 72 . Besides, the students' comprehension about what they talked about was 78. So, the students' speaking average score was about 72. In conclusion, the students' speaking ability regarding to recount text was improved since the score of speaking after completing cycle one was increased from the base score, it was about 68. Based on the data above, the collaborator and the researcher stated that there was an increasing score of the students' speaking ability regarding to recount text from the base score to cycle 1 .

The result of qualitative data analysis shows that there was a factor influence the improvement of students' speaking ability in recount text, it was interest. As mentioned before that video subscribe provides great visual stimuli through their 
combination of illustrations, sounds, graphics, and texts. It makes this media was very interesting for students. So, it could encourage the students' participation and confidence during the process of learning activity especially in speaking regarding to recount text. It helped the students to find out ideas to say. No more students were inactive. They tended to be focus and active in doing communication such as addressing questions and giving comments.

The use of video in teaching speaking designed to make the students motivate and not bored in following the class. To allow work in groups in doing the task also the supported score, this makes the students active in the classroom. The students followed the teaching and learning process well. In the daily meeting, they were enjoying discussing the topics given by the researcher, and they also got new vocabularies, how to pronounce words well, being more confidence during the teaching and learning process especially in understanding the topic given through video subscribe they have watched.

In the other hands, the use of video subscribe was able to improve the students' speaking ability especially in recount text. As Asep Burhanudin (2018) found in his research entitled "The Use of Video in Teaching Speaking Skill: A Classroom Action Research at One of Junior High School in Yogyakarta'. The students show improvements in their pronunciation after learning by using video. Goes along with it, Richards and Renandya (2002) also say that teachers can promote active viewing and increase students' comprehension by implementing teaching and learning process by using video. Besided that, Andriani (2016), on her research finding also states that when the teacher applied video interactive multimedia in teaching, most of students try to be active and have no time to give attention to others. It means that language teaching and learning process is very effective if using a kind of media especially video.

It can be said that teaching using video Subscribe has been used or recognized for many years. Video Subscribe is media that provided audiovisual that could use to help in teachinglearning activities then video subscribe is an online video and using when have been subscribed to the channel Youtube. It is proved that the video has a potential impact on foreign language learning. This is very beneficial for the present linguistic and nonlinguistic aspects. Video subscribe is the best medium to teach speaking a foreign language. A video subscribe presents some extraordinary qualities that make it useful in education or teaching and learning. Lia Selfia Yunita (2015) in her research entitled Effectiveness of Using Video Youtube toward Students Speaking Ability at The Second Grade of MTS PSM Mirigambar. She found that YouTube videos are effective media to improve students' speaking abilities. It was based on the data analysis in which the average score of students' speaking before being taught using YouTube videos is sufficient because the average score of 16 students is 58.4375 . After getting treatment, the average score of students' speaking ability was 67.8125 . It means that there are significant differences in students 'speaking abilities using YouTube.

In conclusion, the students are very enthusiastic about learning how to speak by using video. The students focus on 
watching the content of the video, and most of them raise their hands to answer the teacher's question related to the video. The content of the video provides the motion picture, which is more interesting for the students, and the students focus on watching and trying to understand the content of the video.

\section{CONCLUSSION}

After conducting this Classroom Action Research to solve the students speaking ability by using video subscribe at grade eighth of SMP IT Al Birru, Pekanbaru, the researcher conclude that teaching and learning process is very interesting if it is done by using a media because it provides an important visual stimulus for language practice and learning. So, teachers need to be more creative and innovative in implementing the media so teaching and learning process especially speaking class would be run so fun and students will be motivated.

\section{REFERENCES}

Andriani, R. (2016). Improving Students' Vocabulary Mastery using Interactive Multimedia. ELT-Lectura, 3(1).

Brewster, Jean, Gail Ellis and Denis Girard.(2002). The Primary English Teacher's

Burhanudin, A. (2018). "The Use of Video in Teaching Speaking Skill: A Classroom Action Research at One of Junior High School in Yogyakarta, ELT in Focus, Vol. 1(1).

Cameron, L. (2001). Teaching language to young learners. United Kingdom: Cambridge University Press.

Creswell, J. W. (2012). Educational research: Planning, conducting, and evaluating quantitative and qualitative research (5th ed.). Boston, MA: Pearson.

Deakin Learning Futures Teaching Development Team. 2014. Using audio and video for educational purposes. Available at: deakin.edu.au/learning-futures.

Depdiknas. (2006). Kurikulum Tingkat Satuan Pendidikan (KTSP). Jakarta: Depdiknas.

Gert, R., \& Hans, S. (2008). Handbook of communication competence. Berlin, Germany: University of Bielefeld.

Harmer, J. (2001). The Practice of English Language Teaching. 3rd ed. Cambridge: Pearson Education

Hughes, A. (2003). Testing for Language Teachers. Cambridge: Cambridge University Press.

Mckinnon, M, (2011) Teaching Technologies: Teaching English Using Video. Available at: http://www.onestopenglish.com/suppo rt/methodology/teachingtechnologies/teaching-technologiesteachingenglish-using-video/146527.

Kemendikbud (2013). Kementrian Pendidikan dan Kebudayaan tahun 2013 tentang kriteria Hasil Belajar.

Kemmis, Stephen and Robin Mc Taggard. (2007). Participatory Action Research: Communicative Action in the Public Sphere, in N. Denzin and Y. Lincoln (Eds) Handbook of Qualitative Research. Thousand Oaks, Calif: Sage Publication.

Muniandy, B and Veloo, S. (2011). Managing and Utilizing Online Video Clips for Teaching English Language: Views of TESOL Pre Service Teachers. Singapore: IACSIT Press

Nunan, D. 2003. Practical English Language Teaching. New York: McGraw-Hill. 
Richards, J.C. \& Renandya, W.A. (2002).Methodology in Language Teaching: an Anthology of Current Practice. Cambridge: Cambridge University Press

Silaban, A. L. I., \& Refika, R. (2017). Using Flyswatter Game To Improve Students'vocabulary Mastery At Grade Eigth Smp Dwi Sejahtera Pekanbaru. Elt-Lectura, 4(2).
Winarko, Heri. (2012, February 1st). Retrieved from Traditional Teaching Method vs. Now! website, http://heriwinarko21.blogspot.com/20 12/02/ traditional- teaching-methodvs-now.html.

Yunita, S. L. (2015) "The Effectiveness of Using Video Youtube toward Students Speaking Ability at The Second Grade of MTS PSM Mirigambar, Tulungagung. 